\title{
Analisis Faktor-Faktor Yang Mempengaruhi Perpindahan Pelanggan Pada Toko Retail Komputer Usaha Dagang Mitrakom Yogyakarta
}

\author{
Mardianto ${ }^{1}$ \\ E-mail: mardianto.uad@gmail.com \\ Beni Agus Sulistyo² \\ E-mail: beniagus81@gmail.com \\ Alfredi Rumanjaya ${ }^{3}$ \\ E-mail:alfreyjay2009@gmail.com \\ Aftoni Sutanto 4 \\ E-mail: aftonis@gmail.com \\ Salamatun Asakdiyah ${ }^{5}$ \\ E-mail:salamatun_2009@yahoo.com
}

Porgram Pascasarjana Magister Manajemen Universitas Ahmad Dahlan 1,2,3,4,5

\begin{abstract}
This study aims to analyze the influence of satisfaction (X1), transfer barriers (X2) and complaints (X3) on the transfer of customers at the Mitrakom Yogyakarta retail business retail store. The analytical method in this study is descriptive research with a quantitative approach that uses regression analysis methods, while the testing stages include validity, reliability, classical assumptions, multiple linear regression analysis, determination coefficient ( $\left.r_{\text {square }}\right)$, regression coefficients together ( $f$ test $)$ and hypothesis testing $(t$ test $)$. The population of this research is customers who has conducted transactions at the Mitrakom Yogyakarta retail retail store. The technique of taking research samples is using purposive sampling method. The number of questionnaires distributed amounted to 136 copies. Validity and reliability test results are valid and reliable. Hypothesis testing provides results that simultaneously show the influence of the three variables studied proved to significantly affect the dependent variable of customer displacement. These results indicate that the ups and downs of customer movements at the Mitrakom Yogyakarta trading business shop does not depend on the ups and downs of satisfaction levels, transfer hurdles and complaints obtained by customers. The coefficient of determination (adjusted $r_{\text {square }}$ ) is obtained by 0.630 which indicates that $63 \%$ of customer transfers can be explained by its independent variables and the remaining $37 \%$ is explained by other factors outside the variables not included in this study. Furthermore, the results of research through statistical analysis have proven the truth of the four hypotheses in this study.
\end{abstract}

Keywords: Satisfaction, transfer barriers, complaints and customer transfers

\section{Abstrak}

Penelitian ini bertujuan untuk menganalisis sejauh mana pengaruh kepuasan (X1), rintangan pengalihan (X2) dan keluhan (X3) terhadap perpindahan pelanggan pada toko retail usaha dagang Mitrakom Yogyakarta. Metode analisis pada penelitian ini adalah penelitian deskriptif dengan pendekatan kuantitatif yang menggunakan metode analisis regresi, sedangkan tahap-tahap pengujiannya meliputi validitas, reliabilitas, asumsi klasik, analisis regresi linier berganda, koefisiensi determinasi ( $\left.r_{\text {square }}\right)$, koefisien regresi secara bersama-sama (uji $\left.f\right)$ dan pengujian hipotesis (uji -t). Populasi penelitian ini adalah pelanggan yang melakukan transaksi pada toko retail usaha dagang Mitrakom Yogyakarta.Teknik pengambilan sampel penelitian menggunakan metode purposive sampling. Jumlah kuesioner yang disebarkan berjumlah 136 eksemplar. Hasil uji validitas dan reliabilitas sudah valid dan reliabel. Pengujian hipotesis memberikan hasil bahwa secara simultan menunjukkan pengaruh ketiga variabel yang diteliti terbukti secara signifikan mempengaruhi variabel dependen perpindahan pelanggan. Hasil 
ini mengindikasikan bahwa naik turunnya perpindahan pelanggan pada toko usaha dagang Mitrakom Yogyakarta tidak tergantung pada naik turunnya tingkat kepuasan, rintangan pengalihan dan keluhan yang diperoleh pelanggan. Diperoleh nilai koefisien determinasi (adjusted $r_{\text {square }}$ ) sebesar 0,630 yang menunjukkan bahwa sebesar 63\%perpindahan pelanggan dapat dijelaskan oleh variabel independennya dan sisanya 37\% dijelaskan oleh faktor lain di luar variabel yang tidak dimasukkan dalam penelitian ini. Selanjutnya hasil penelitian melalui analisis statistik telah membuktikan kebenaran keempat hipotesis dalam penelitian ini.

Kata kunci: Kepuasan, rintangan pengalihan, keluhan dan perpindahan pelanggan.

\section{PENDAHULUAN}

Penelitian ini diinisiasi dari model penelitian Anreassen (1999) bahwa bagi suatu perusahaan semakin lama pelanggan bertahan maka semakin berharga pula pelanggan tersebut. Pelanggan lama kurang sensitif terhadap harga dan pada umumnya akan membawa pelanggan lain. Hal tersebut membawa dampak positif bagi perusahaan dikarenakan perusahaan tidak perlu mengeluarkan biaya yang lebih untuk menarik pelanggan baru.Konsumen yang hampir selalu melakukan pembelian pada suatu perusahaan atau merek tertentu dan mempunyai suatu kekuatan dan sikap positif terhadap perusahaan tersebut.

Daya beli yang relatif stabil dan kecendrungan adanya peningkatan akibat perbaikan perekonomian yang semakin baik dewasa ini mengakibatkan pola beli dari pelanggan mengalami perubahan. Hal ini dimungkinkan karena banyaknya perusahaan-perusahaan baru yang sejenis masuk ke pasar yang sama, begitu pula banyaknya varian-varian dan merek-merek baru masuk ke pasar yang mengakibatkan tekanan-tekanan persaingan yang mengarah pada perubahan loyalitas pelanggan dan berdampak negatif, akibatnya kecenderungan perpindahan pelanggan semakin meningkat (Adiwijaya, 2007).

Konsumen yang hampir selalu melakukan pembelian pada suatu perusahaan atau merk tertentu dan mempunyai suatu kekuatan dan sikap positif terhadap perusahaan tersebut.Hal yang paling signifikan dengan mempertahankan pelangggan adalah loyalitas pelanggan.Sedangkan loyalitas pelanggan berkaitan langsung dengan kepuasan pelanggan, rintangan pengalihan dan keluhan pelanggan.Fakta empiris membuktikan adanya hubungan kepuasan dengan loyalitas yang rendah korelasinya (Lovelock, 2001).

Toko komputer kini dengan mudah dapat ditemui di Yogyakarta. Perusahaan harus meningkatkan kemampuan yang handal dalam menghadapi persaingan, upaya ini dapat dilakukan dengan cara menjual produk berkualitas, harga yang bersaing, pendistribusian yang cepat dan tepat waktu serta pelayanan terbaik akan mampu menjadikan perusahaan tetap bertahan. Sejalan dengan perkembangan pola hidup serta kebutuhan masyarakat terhadap produk dan jasa computer yang semakin komplek, menciptakan persaingan yang semakin ketat dan sempitnya ruang gerak pemasaran bagi perusahaan sejenis.Dengan semakin banyaknya usaha sejenis yang muncul menyebabkan konsumen mempunyai banyak altematif serta semakin selektif di dalam menentukan pilihan.

Oleh karena itu pemasaran tidak saja dituntut menjual produk dan jasa, melainkan juga harus mengetahui bagaimana menyajikan altematif terbaik ke pasar yang menjadi sasaran dibanding dengan persaingan. Berawal dengan kondisi tersebut, menuntut pengelola usaha pada umumnya agar dapat mengetahui informasi sebanyak 
mungkin atau untuk selalu memperbaiki perkenalan terhadap konsumen, mengidentifikasi kembali kebutuhan mereka, baik untuk masa sekarang dan akan datang.

Usaha dagang Mitrakom Yogyakarta merupakan usaha yang bergerak dibidang penjualan retail berbagai macam produk computer seperti notebook, netbook, PC built up, PC rakitan, Sparepart computer, peralatan jaringan (network), aksesories komputer dan jasa perbaikan dan dan lainnya, berlokasi di Komplek Pertokoan Gajah Mada Square Kav.F Yogyakarta.Daerah yang merupakan pusat bisnis dan sangat ideal karena sangat dekat dengan pusat perkantoran, hotel, pertokoan, kampus dan lainya sehingga banyak yang membutuhkan pembelian produk dan perawatan serta perbaikan komputer.

Fenomena yang terjadi sangat kontradiktif disatu sisi tingkat pertumbuhan omzet meningkat tetapi disisi lainnya jika dilihat perkembangan dari tahun ke tahun tampak adanya penurunan, yaitu dari 37,78\% pada tahun 2013 turun menjadi 18,35\% pada tahun 2017. Dari tabel diatas terlihat bahwa jumlah pelanggan dari tahun ke tahun terus meningkat akan tetapi pelanggan lama tidak dapat dipertahankan. Meskipun perusahaan berhasil mendapatkan pelanggan baru namun pelanggan yang tidak berlangganan lagi cukup signifikan hal ini menggambarkan bahwa kondisi hilangnya pelanggan lama tersebut mengindikasikan adanya permasalahan dalam loyalitas pelanggan yang disebabkan oleh ketiga faktor tersebut diatas yaitu kepuasan pelanggan, rintangan pengalihan dan keluhan pelangga.

Pada penelitian ini menggunakan rumusan masalah yang akan diuraikan menyangkut permasalahan yang dihadapi oleh usaha dagang Mitrakom Yogyakarta yang berkaitan dengan kerentanan terjadinya perpindahan pelanggan dimana sebahagian besar pelanggan lama tidak mampu untuk dipertahankan. Pelanggan lama seharusnya dapat mendatangkan keuntungan yang lebih besar bila dibandingkan dengan pelanggan baru. Ketidak mampuan proses bisnis mempertahankan pelanggan lama dalam jangka panjang akan mempengaruhi tingkat ketidak percayaan pelanggan baru.

Sesuai dengan hasil studi dari Fornell (1992), menunjukkan bahwa terdapat beberapa faktor yang mempengaruhi dan berkaitan dengan loyaliatas pelanggan, yaitu kepuasan, rintangan pengalihan dan keluhan. Mengacu pada permasalahan tersebut maka permasalahan yang diajukan dalam penelitian ini adalah: 1) Apakah ada keterkaitan antara kepuasan pelanggan terhadap perpindahan pelanggan pada usaha dagang Mitrakom Yogyakarta? 2) Apakah ada keterkaitan antara rintangan pengalihan terhadap perpindahan pelanggan pada usaha dagangMitrakom Yogyakarta? 3) Apakah ada keterkaitan antara keluhan pelanggan terhadap perpindahan pelanggan pada usaha dagang Mitrakom Yogyakarta? 4) Apakah ada pengaruh yang simultan antara kepuasan pelanggan, rintangan pengalihan dan keluhan pelanggan terhadap perpindahan pelanggan pada usaha dagang Mitrakom Yogyakarta?

\section{TINJAUAN PUSTAKA}

Menurut Tjiptono (2008) kepuasan konsumen adalah perbandingan persepsi konsumen terhadap suatu produk dengan harapan dan kinerja aktual produk yang dirasakan. Pada persaingan yang semakin ketat ini, semakin banyak produsen yang terlibat dalam pemenuhan kebutuhan dan keinginan konsumen sehingga hal ini menyebabkan setiap perusahaan harus menempatkan orientasi pada kepuasan konsumen sebagai tujuan 
utama, antara lain dengan semakin banyaknya perusahaan yang menyatakan komitmennya terhadap kepuasan konsumen dalam pernyataan misi iklan, hal ini desebabkan kareana kepuasan pelanggan sangat berpengaruh terhadap kerentanan terjadinya perpindahan pelanggan.

Menurut Hawkins, Best, Roger dan Coney (2008), atribut-atribut pembentuk kepuasan konsumen dikenal dengan "The Big Eight" yang terdiri dari: Value to price relationship. Artinya bahwa hubungan antara harga dan nilai produk ditentukan oleh perbedaan antara nilai yang diterima pelanggan terhadap produk yang dihasilkan oleh badan usaha meliputi 1) Kualitas produk, artinya merupakan mutu dari semua komponen yang membentuk produk sehingga produk tersebut mempunyai nilai tambah. 2) Product feature, artinya merupakan komponen-komponen fisik dari suatu produk yang dihasilkan. 3) Reliability, artinya merupakan gabungan dari kemampuan suatu produk dari badan usaha yang dapat diandalkan, sehingga suatu produk yang dihasilkan dapat sesuai dengan apa yang dijanjikan oleh badan usaha. 4) Warranty, artinya penawaran untuk pengembalian harga pembelian atau mengadakan perbaikan terhadap produk yang rusak dalam suatu kondisi dimana suatu produk mengalami kerusakan setelah pembelian. 5) Response to and remedy of problems, artinya merupakan sikap dari karyawan didalam memberikan tanggapan terhadap keluhan atau membantu pelanggan didalam mengatasi masalah yang terjadi. 6) Sales experience, artinya merupakan hubungan semua antar pribadi antara karyawan dengan pelanggan khususnya dalam hal komunikasi yang berhubungan dengan pembelian. 7) Convenience of acquisition, artinya merupakan kemudahan yang diberikan oleh badan usaha kepada pelanggan terhadap produk yang dihasilkan.

Dewasa ini, konsep kepuasan pelanggan terus mengalami perkembangan, sehingga terdapat berbagai definisi mengenai kepuasan pelanggan, yaitu: Day (Tse dan Wilton, 1988) menyatakan bahwa kepuasan atau ketidakpuasan pelanggan adalah respon pelanggan terhadap evaluasi ketidak sesuaian (disconfirmation) yang dirasakan antara harapan sebelumnya dan kinerja aktual produk yang dirasakan setelah pemakaiannya. Wilkie (1990)mengemukakan bahwa kepuasan pelanggan merupakan suatu tanggapap emosional pada evaluasi terhadap pengalaman konsumsi suatu produk atau jasa. Engel, Blacwell dan Miniard (1990) menyatakan bahwa kepuasan pelanggan merupakan evaluasi purnabeli di mana alternatif yang dipilih sekurang-kurangnya sama atau melampaui harapan pelanggan, ketidakpuasan akan timbul apabila hasil (out come) tidak memenuhi harapan. Kotler (1996) menandaskan bahwa kepuasan pelanggan adalah tingkat perasaan seseorang setelah membandingkan hasilyang dirasakandengan harapannya.Definisi-definisi di atas disimpulkan oleh Tjiptono (1997) bahwa pada dasamya pengertian kepuasan pelanggan mencakup perbedaan antara harapan dan kinerja atau hasil yang dirasakan.

Faktor yang sering digunakan dalam mengevaluasi kepuasan terhadap produk menurut Garvin dan Lovelock (1994), Peppard dan Rowland (1995) antara lain meliputi kinerja (performance) karakteristik operasi pokok dari produk inti yang dibeli, misalnya harga; kualitas yang dipersepsikan (perceived quality); estetika, yaitu daya tarik produk terhadap panca indera, misalnya bentuk fisik (desain produk) dan kesesuaian dengan spesifikasi (conformance to specifications). Maka dapat dibuat hipotesis H1: Semakin tinggi tingkat kepuasan pelanggan, maka semakin rendah kerentanan perpindahan pelanggan. 
Rintangan Pengalihan (Switching Barriers).Menurut Claes (2009) hambatan berpindah adalah segala faktor yang mempersulit atau memberikan biaya kepada pelanggan jika beralih penyedia jasa. Tiga jenis biaya peralihan antara lain,1) Transaction Cost, yaitu sejumlah uang yang dikeluarkan oleh pelanggan ketika berganti penyedia jasa sebagai balas jasa. 2) Learning Cost, merupakan pembelajaran yang dipandang sebagai proses dimana pengalaman menyebabkan perubahan dalam pengetahuan, sikap dan atau perilaku. Sehingga jika konsumen beralih dari penyedia jasa tempat konsumen berlangganan, konsumen harus menyesuaikan diri kembali dengan tempat berlangganan sekarang. 3) Artificial Cost, yaitu biaya yang berasal dari perusahaan itu sendiri untuk mempertahankan pelanggannya.

Perusahaan memberikan pelayanan pelengkap yang disesuaikan dengan kebutuhan pelanggan.Jones dan Ioannou (2008) menjabarkan hambatan berpindah adalah sebuah faktor yang menimbulkan kesulitan atau memakan biaya dan waktu bagi konsumen untuk merubah perusahaan.Menurut Patterson, Evelyn and Smith (2003) switching barriers dapat dikategorikan menjadi enam, yaitu: biaya pencarian, hilangnya ikatan sosial, biaya persiapan, biaya jasa, risiko fungsional, daya tarik alternatif, dan hilangnya manfaat perlakuan khusus.

Strategi ofensif terutama ditujukan untuk meraih atau memperoleh peianggan baru, sehingga perusahaan diharapkan dapat meningkatkan pangsa pasar, penjualan, dan jumlah pelanggannya. Sedangkan strategi defensif meliputi usaha untuk mengurangi kemungkinan customer exit dan beralihnya peianggan ke pemasar lain. Strategi defensif terdiri dari dua bentuk, yaitu rintangan pengalihan dan kepuasan pelanggan (Tjiptono, 1997).

Rintangan pengalihan merupakan suatu upaya dari perusahaan untuk membentuk suatu halangan (barriers), sehingga pelanggan merasa enggan, rugi, atau perlu mengeluarkan biaya besar untuk berganti pemasok (suplier, toko dan lain-lain). Rintangan pengalihan ini dapat berupa biaya pencarian, biaya transaksi, biaya belajar atau pemahaman, potongan harga khusus bagi pelanggan yang loyal, kebiasaan pelanggan, biayabiaya emosional, dan usaha-usaha kognitif, serta risiko finansial, sosial, dan psikologis (Fornell, 1992). Selain itu juga dapat berupa biaya latihan tambahan bagi karyawan, modal yang diperlukan untuk perubahan, serta biaya yang diperlukan dalam peralatan pelengkap yang baru (Porter, 1980). Berdasarkan uraian tersebut, maka dapat dibuat hipotesis $\mathrm{H} 2$ : Semakin baik pembentukan rintangan pengalihan, maka semakin rendah kerentanan perpindahan pelanggan.

Keluhan (Voice)merupakan kepuasan atau ketidakpuasan yang dapat timbul karena adanya proses evaluasi terhadap produk dan jasa pasca pembelian seperti keluhan karena pelayanan dari pegawai yang tidak menyenangkan, hasil yang tidak diinginkan dan penggunaan produk yang tidak sesuai dengan janji-janji. Sistem penanganan keluhan yang efektif membutuhkan prosedur yang ketat untuk menyelesaikan masalah.Sistem ini harus didukung oleh sumber daya manusia serta infrastruktur yang memadai agar kinerjanya memuaskan. Personal harus dilatih agar dapat menangani masalah yang terjadi dengan cara yang memuaskan pelanggan.

Keluhan merupakan komplain dari pelanggan yang merasa tidak puas (Tjiptono, 1997). Menurut Singh (1988), ada tiga kategori komplain terhadap ketidakpuasan, yaitu 1) Voice response, kategori ini meliputi usaha menyampaikan keluhan secara langsung dan atau meminta ganti rugi kepada perusahaan. Salah satu manfaat dari komplain kategori ini adalah memberi masukan mengenai kekurangan pelayanan yang perlu di perbaiki 
perusahaan.2) Private response, pada komplain kategori ini, tindakan yang dilakukan antara lain memperingatkan atau memberi tahu kolega, teman, atau keluarganya mengenai pengalaman pelanggan dengan produk atau perusahaan yang bersangkutan.Pada umumnya dampak dan tindakan pelanggan tersebut sangat besar bagi citra perusahaan. 3)Thirdparty response, Tindakan yang dilakukan pada kategori ini adalah meliputi meminta ganti rugi secara hukum, mengadu lewat media masa atau lembaga konsumen.

Menurut Tjiptono (1997) ada empat aspek penting dalam menangani keluhan pelanggan, yaitu: 1) Empati terhadap pelanggan yang marah Pihak perusahaan perlu meluangkan waktu untuk mendengarkan keluhan pelanggan dan berusaha memahami situasi yang dirasakan pelanggan. 2) Kecepatan dalam menangani keluhan merupakan hal yang sangat penting dalam penanganan keluhan sebab ada kemungkinan pelanggan menjadi puas sehingga akan kembali menjadi pelanggan. 3) Kewajaran atau keadilan dalam menangani keluhan disini dalam pengertian win-win solution, artinya pelanggan dan perusahaan sama ssama diuntungkan. 4) Akses merupakan faktor yang juga penting bagi pelanggan untuk menyampaikan komentar, saran, kritik, pertanyaan, maupun keluhan. Berdasarkan uraian tersebut, maka dapat dibuat hipotesis H3:Semakin baik penangganan keluhan, maka semakin rendah kerentananperpindahan pelanggan.

Kerentanan perpindahan pelanggan menurut Dick dan Basu (1999), loyalitas pelanggan berkembang melalui empat tahap, yaitu tahap kognitif, afektif, konatif, dan tindakan.Pada tahap kognitif, konsumen menggunakan basis informasi yang secara memaksa menunjuk pada satu merek atas merek lainnya.Loyalitas kognitif lebih didasarkan pada karakteristik fungsional, terutama biaya, manfaat, dan kualitas, oleh karena itu loyalitas pada tahap ini sangat rentan dengan perpindahan merek.Loyalitas tahap afektif didasarkan pada aspek afektif konsumen, sehingga loyalitas pada tahap ini lebih kuat jika dibandingkan pada loyalitas kognitif, sebab loyalitasnya sudah masuk ke dalam benak konsumen sebagai afek bukannya sebagai kognisi yang mudah berubah.Loyalitas konatif merupakan suatu kondisi loyal yang mencakup komitmen mendalam untuk melakukan pembelian.Komitmen berarti sudah melampaui afektif, bagian dari properti motivasional untuk mendapatkan merek yang disukai. Pada loyalitas tahap ini, kerentanan konsumen lebih terfokus pada faktor persuasi dan upaya mencoba merek lain. Pada loyalitas tindakan, konsumen kebal terhadap upaya pemasaran baik dari merek pesaing, komunikasi dan strategi pemasaran merek lain tidak banyak mendapatkan perhatian. Hal ini disebabkan konsumen tidak melakukan pencarian informasi dan evalusi.Assael (1995) memasukkan kebiasaan dan perilaku respon yang sudah rutin ke dalam loyalitas tindakan ini.Hasil studi dari M. Zein (1995) menunjukkan pentingnya pengalaman masa lampau dalam bisnis eceran, sebab antara pengalaman pembelian masa lampau dengan kerentanan perpindahan pelanggan terhadap sebuah toko memiliki hubungan yang signifikan. Pada penelitian tersebut pengalaman masa lampau dengan sebuah toko dioperasionalkan oleh dua variabel, yaitu kepuasan dari pembelian lampau dengan mengacu pada kualitas barang, harga, pelayanan, dan keseluruhan aspek dari toko dan variabel yang kedua adalah memperluas keinginan untuk merekomendasikan toko pada kawan atau keluarganya. Keputuasan untuk memasukkan variabel kedua untuk ukuran pengalaman masa lampau berdasar pada peranan bahwa berita dari mulut ke mulut berperan, tidak hanya dalam hal menyebarkan informasi, tetapi juga dalam mengekspresikan pengalaman (Swan dan Oliver, 1989).Berdasarkan uraian 
tersebut, maka dapat dibuat hipotesis $\mathrm{H} 4$ :Semakin baik penangganan kepuasan, rintangan pengalihan dan keluhan, maka semakin rendah kerentanan perpindahan pelangganpada usaha dagang Mitrakom Yogyakarta.

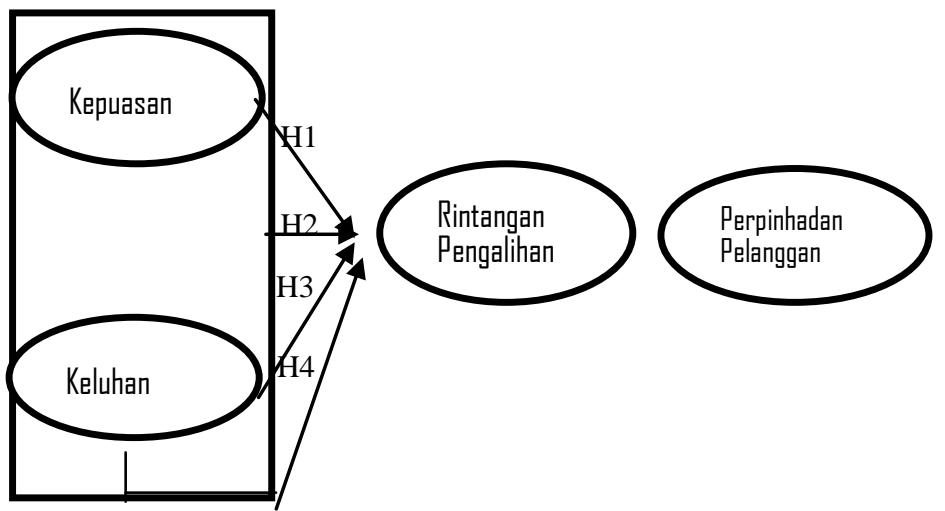

Gambar 1. Kerangka Konseptual

Pada Penelitian ini hubungan antar variabel dilakukan dengan menggunakan hipotesis. Hipotesis adalah hubungan yang diperkirakan secara logis di antara dua atau lebih variabel yang diungkapkan dalam bentuk pernyataan yang dapat diuji.Hubungan tersebut diperkirakan berdasarkan jaringan asosiasi yang ditetapkan dalam kerangka teoritis yang dirumuskan untuk studi penelitian. Dengan menguji hipotesis akan menegaskan perkiraan hubungan, diharapkan bahwa solusi dapat ditemukan untuk mengatasi masalah yang dihadapi (Sekaran,2006:135). Sedangkan hipotesis dalam penelitian ini adalah:

H1: Ada pengaruh yang signifikan antara kepuasan pelanggan terhadap perpindahan pelanggan pada usaha dagangMitrakom Yogyakarta.

H2: Ada pengaruh yang signifikan antara rintangan pengalihan terhadap perpindahan pelanggan pada usaha dagang Mitrakom Yogyakarta.

H3:Ada pengaruh yang signifikan antara keluhan pelanggan terhadap perpindahan pelanggan pada usaha dagang Mitrakom Yogyakarta.

H4: Ada pengaruh simultan yang signifikan antara kepuasan pelanggan, rintangan pengalihan dan keluhan pelanggan terhadap perpindahan pelanggan pada usaha dagang Mitrakom Yogyakarta.

\section{METODE PENELITIAN}

Populasi dalam penelitian ini adalah seluruh pelanggan usaha dagang Mitrakom Yogyakarta yang memiliki ciri-ciri atau karakter terdiri dari elemen populasi sebagai berikut: konsumen yang berlangganan dalam 1 tahun terakhir pada usaha dagang Mitrakom Yogyakarta. Sampel pada penelitian ini diambil dari pelanggan usaha dagang Mitrakom Yogyakarta terutama data tahun terakhir. Pertimbangan diambilnya data tahun terakhir adalah untuk bisa mendapatkan data terkini, selain itu data tahun terakhir berarti juga pelanggan tahun-tahun sebelumnya terwakili, dimana juga jumlahnya ternyata terbesar.Metode yang digunakan untuk memilih sampel penelitian dalam studi ini adalah metode purposive sampling yang merupakan salah satu jenis metode nonprobability sampling yaitu memilih konsumen secara mudah dengan kriteria tertentu. 
Sampling ini merupakan sampel non probabilitas yang memenuhi kriteria tertentu.Tujuan menggunakan metode ini untuk mendapatkan subjek penelitian yang bisa memberikan informasi akurat.Data penelitian terdiri atas data primer dan data sekunder.Data primer diperoleh melalui survei dengan menyebarkan kuesioner pada pelanggan usaha dagangMitakom.Responden diminta untuk mengisi butir-butir pengukuran konstruk model penelitian. Para responden diminta mengisi kuesioner sesudah melakukan transaksi pembelian.Dari hasil perhitungan sampel yang diambil minimal 136 orang pelanggan sebagai responden, namun unit analisis penelitian adalah pelanggan yang berdomisili di Yogjakarta. Untuk data sekundernya bersumber dari usaha dagang Mitrakom Yogyakarta antara lain meliputi: nilai penjualan, jumlah pelanggan dan lain-lain.

Definisi operasional dari variabel-variabel yang dianalisis dalam penelitian ini adalah:

1) Kepuasan pelanggan (X1) merupakan tingkat perasaan pelanggan setelah membandingkan kinerja yang pelanggan rasakan dibandingkan dengan harapannya yang diukur dengan pernyataan. Faktor-faktor yang berhubungan dengan produk: 1) Value to price relationship, 2) Product quality, 3) Desain Product. Harapan pelanggan adalah harapan responden terhadap dimensi produk komputer yang meliputi produk, harga, dan layanan. Variabel ini akan diukur dengan skala likert yang kriterianya mulai dari sangat tidak penting (1) s/d sangat penting (5) sedangkan kinerja perusahaan adalah persepsi responden terhadap kinerja dimensi produk komputer yang meliputi produk, harga, dan layanan. Variabe ini akan di ukur dengan skala likert yang kriterianya mulai dari 1 (sangat tidak setuju) s/d 5 (sangat setuju).

2) Rintangan pengalihan (X2) merupakan sebuah faktor yang menimbulkan kesulitan atau memakan biaya dan waktu bagi pelanggan untuk merubah perusahaan yang diukur dengan 1) Transaction Cost, 2) Learning Cost, 3) Artificial Cost. Rintangan pengalihan adalah persepsi responden terhadap bentuk-bentuk rintangan pengalihan yang ada pada perusahaan yang meliputi potongan harga, cara pembayaran, dan garansi. Variabel ini akan diukur dengan skala likert yang kriterianya mulai dari 5 (sangat setuju) s/d 1 (sangat tidak setuju).

3) Keluhan (X3) merupakan persepsi responden terhadap penanganan keluhan oleh perusahaan yang meliputi empati terhadap pelanggan, kecepatan dalam menangani keluhan, dan akses. Variabel ini akan diukur dengan skala likert yang kriterianya mulai dari 5 (sangat setuju) s/d 1 (sangat tidak setuju).

\section{HASIL PENELITIAN}

Dari data kuesioner yang memenuhi syarat dan diolah adalah 136 responden, maka diproleh hasil:

\begin{tabular}{lcc} 
Karakteristik & Jumlah (orang) & Persens \\
\hline $\begin{array}{l}\text { Jenis kelamin } \\
\text { Laki-laki }\end{array}$ & 78 & $57,35 \%$ \\
Perempuan & 58 & $42,65 \%$ \\
& & \\
Usia & & \\
$09-17$ tahun & 20 & $14,71 \%$ \\
$18-30$ tahun & 48 & $35,29 \%$ \\
$31-40$ tahun & 39 & $28,68 \%$ \\
$41-50$ tahun & 19 & $13,37 \%$
\end{tabular}




\begin{tabular}{lll}
$>51$ tahun & 10 & $7,35 \%$ \\
Pekerjaan & & \\
Peg. BUMN & 36 & $26,47 \%$ \\
PNS / ABRI & 8 & $5,89 \%$ \\
Peg. Swasta & 42 & $30,88 \%$ \\
Mahasiswa / Pelajar & 38 & $27,94 \%$ \\
Penghasilan & & \\
$<2,5$ jt & 43 & $31,62 \%$ \\
2,5 jt -5 jt & 41 & $30,15 \%$ \\
5 jt $-7,5$ jt & 33 & $24,26 \%$ \\
7,5 jt -10 jt & 13 & $9,56 \%$ \\
$>10$ jt & 6 & $4,41 \%$ \\
\hline
\end{tabular}

Sumber: data primer yang diolah, 2018

Koefisien determinasi sebesar 0,630 yang menunjukkan bahwa sebesar $63 \%$ perpindahan pelanggan dapat telah dapat dijelaskan oleh variabel independennya sisanya $(100 \%-63 \%=37 \%)$ dijelaskan oleh faktor lain di luar variabel yang tidak dimasukkan dalam penelitian ini.

Nilai koefisien variabel $X 1$ adalah 0.595 . Nilai signifikansi variabel $X 1$ adalah 0,030 yang lebih kecil dari $\alpha=0,05$. Maka variabel X1 berpengaruh positif dan signifikan terhadap Perpindahan Pelanggan dan nilai koefisien variabel $X 2$ adalah 0.593 . Nilai signifikansi variabel $X 2$ adalah 0,013 yang lebih kecil dari $\alpha=0,05$. Maka variabel $\mathrm{X} 2$ berpengaruh positif dan signifikan terhadap Perpindahan Pelanggan serta nilai koefisien variabel X3 adalah 0.480 . Nilai signifikansi variabel $X 3$ adalah 0,021 yang lebih kecil dari $\alpha=0,05$. Maka variabel $X 3$ berpengaruh positif dan signifikan terhadap Perpindahan Pelanggan

Dengan menggunakan tingkat keyakinan 95\%, df 1 (jumlah variabel-1) $=9$, dan df 2 (n-k-1) $=126$, hasil diperoleh untuk $F$ tabel sebesar 3,058 dengan nilai signifikansi sebesar 0,000 . Sehingga nilai $F$ hitung $>F$ tabel $(26.532>3,058)$ atau nilai $p<a(0,00<0,05)$, maka Ho ditolak, artinya secara bersama-sama variabel kepuasan, rintangan pengalihan dan keluhan berpengaruh secara signifikan terhadap perpindahan pelanggan.

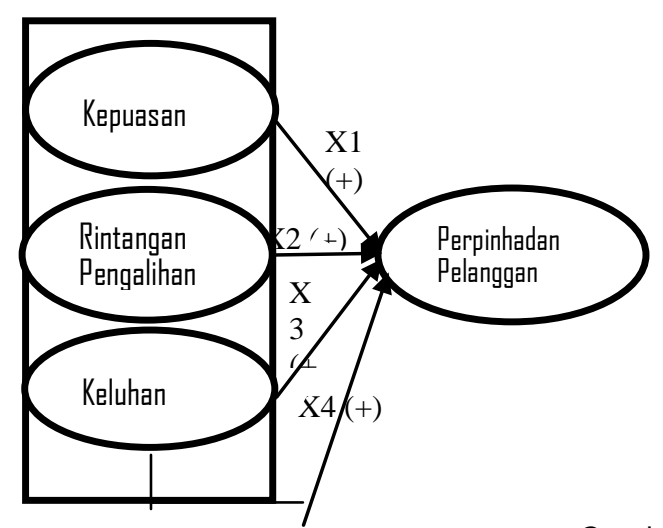

Gambar 2. Kerangka Konseptual

Berdasarkan data diatas hasil penelitian terhadap kepuasan, rintangan pengalihan dan keluhan berpengaruh positif dan signifikan terhadap perpindahan pelanggan, hal ini dapat membuktikan masing-masing hipotesa yang diteliti sebagai berikut:

1) Hipotesis pertama yang menyatakan semakin tinggi tingkat kepuasan pelanggan, maka semakin rendah kerentanan perpindahan pelanggan yang diuji dengan analisis chi kuadrat dan hasilnya menunjukkan $\mathrm{HO}$ ditolak, 
berarti hipotesis pertama yang diajukan dalam penelitan ini telah terbukti kebenaranya. Hasil ini sejalan dengan hasil penelitian yang telah dilakukan oleh Fornell (1992) yang menyatakan adanya hubungan yang significan antara perpindahan pelanggan dengan kepuasan pelanggan. 2) Hipotesis kedua yang menyatakan bahwa semakin baik pembentukan terhadap rintangan pengalihan, maka semakin rendah kerentanan perpindahan pelanggan diuji dengan analisis chi kuadrat dan hasilnya menunjukkan $\mathrm{HO}$ ditolak, berarti hipotesis kedua yang diajukan dalam penelitan ini telah terbukti kebenaranya. Hasil ini juga sejalan dengan hasil penelitian yang telah dilakukan oleh Fornell (1992) yang menyatakan adanya hubungan yang signifikan antara perpindahan pelanggan dengan rintangan pengalihan yang merupakan salah satu variabel yang memiliki keterkaitan dengan loyalitas pelanggan.3) Hipotesis ketiga yang menyatakan bahwa semakin baik penangganan keluhan, maka semakin rendah kerentanan perpindahan pelanggan diuji dengan analisis chi kuadrat dan hasilnya menunjukkan HO ditolak, sehingga hipotesis ketiga yang diajukan dalam penelitan ini telah terbukti kebenaranya. Hasil ini juga sejalan dengan hasil penelitian yang telah dilakukan oleh Fornell (1992) yang menyatakan bahwa variabel keluhan memiliki hubungan yang significan dengan perpindahan pelanggan dan keluhan merupakan salah satu variabel yang memiliki keterkaitan dengan loyalitas pelanggan. 4) Hipotesis keempat yang menyatakan bahwa ada pengaruh simultan yang signifikan antara kepuasan pelanggan, rintangan pengalihan dan keluhan pelanggan terhadap perpindahan pelanggan usaha dagang Mitrakom Yogyakarta diuji dengan uji $\mathrm{F}$ dan hasilnya menunjukkan $\mathrm{H}_{0}$ ditolak, sehingga hipotesis keempat yang diajukan dalam penelitan ini telah terbukti kebenaranya. Hasil ini juga sejalan dengan hasil penelitian yang telah dilakukan oleh Fornell (1992) yang menyimpulkan ketiga variabel yaitu kepuasan pelanggan, rintangan pengalihan dan keluhan telah terbukti secara signifikan mempengaruhi perpindahan pelanggan secara bersama-sama.

\section{KESIMPULAN DAN SARAN}

Keterkaitan antara kepuasan pelanggan terhadap perpindahan pelanggan pada usaha dagang Mitrakom Yogyakarta adalah positif dan signifikan.Temuan ini menjelaskan bahwa rumusan hipotesis tidak terdukung karena semakin tinggi kepuasan pelanggan, maka semakin tinggi kerentanan perpindahan pelanggan. Keterkaitan antara rintangan pengalihan terhadap perpindahan pelanggan pada usaha dagang Mitrakom Yogyakarta adalah positif dan signifikan.Temuan ini menjelaskan bahwa rumusan hipotesis tidak terdukung karena yang berarti bahwa semakin tinggi pembentukan rintangan pengalihan, maka semakin tinggi kerentanan perpindahan pelanggan.

Keterkaitan antara keluhan pelanggan terhadap perpindahan pelanggan pada usaha dagang Mitrakom Yogyakarta adalah positif dan signifikan.Temuan ini menjelaskan bahwa rumusan hipotesis tidak terdukung karena yang berarti bahwa semakin tinggi penangganan keluhan, maka semakin tinggi kerentanan perpindahan pelanggan. Pengaruh yang simultan antara kepuasan pelanggan, rintangan pengalihan dan keluhan pelanggan terhadap perpindahan pelanggan pada usaha dagang Mitrakom Yogyakarta adalah positif dan signifikan yang berarti bahwa secara bersama sama ketiga variabel tersebut turut mengakibatkanterjadinya kerentanan perpindahan pelanggan. 


\section{DAFTAR PUSTAKA}

Adiwijaya, Michael. 2007. Analisa Strategi Reposisi Merek Dalam Persaingan Pasar. Jurnal Manajemen Pemasaran. Vol. 2.No. 2.

Andreassen, TW. 1999. What Drives Customer Loyalty with Complaint Resolution. Journal of Service Research.Vol. 1. No 4.

Assael, Henry. 1995. Costumer Behavior and Marketing Action. Keat Publishing Company, Boston.

Azwar. 1997. Metode Penelitian Jilid I. Pustaka Pelajar. Yogyakarta.

Dick, A. dan K Basu. 1994. Consumer Loyalty: Toward an Integrated Conceptual Framework. Journal of the Academy of Marketing Science.Vol. 22.

Chen, Yenny dan Edwin J. 2014. Pengaruh Kepuasan, Hambatan Berpindah, dan Penyediaan Fasilitas Terhadap Loyalitas Konsumen di Hotel Novotel Surabaya. Jurnal Strategi Pemasaran. Vol. 2.No. 1.

Djarwanto, dan Subagyo P. 2000.Statistik Induktif. BPFE. Yogyakarta.

Engel, James F., Blacwell Roger D dan Miniard Paul W. 1990. Consumer Behavior. Dryden Press. New York.

Ferdinand, Augusty. 2006. Metode Penelitian Manajemen: Pedoman Penelitian untuk skripsi, Tesis dan Disertai IImu Manajemen. Universitas Diponegoro. Semarang.

Fornell, C. 1992. Customer Satisfaction, Market Share, and Profitability: Findings from Sweden. Journal of Marketing, 56, 6-21.

Claes, Fornell, 2009. Customer Satisfaction, Market Share, and Profitability: Findings from Sweden. Journal of Marketing, Vol. 58, July: 53-66.

Garvin, D.A dan Lovelock. 1994. Competing on the Eight Dimension of Quality. Harvard Business Review Journal.

Ghozali, Imam. 2011. Aplikasi Analisis Multivariate Dengan Program SPSS. Badan Penerbit Universitas Diponegoro. Semarang.

Hasan, Iqbal. 1999. Pokok-Pokok Materi Statistika 2 (Statistik Inferensif). Bumi Aksara. Jakarta.

Hawkins, Del I., Best, Roger dan Coney, Kenneth. 2008. Consumer Behavior: Implication for Marketing Strategy, Fifth Edition. Richard D. Irwin, Inc. New York.

Hurriyati, Ratih. 2005. Bauran Pemasaran dan Loyalitas Konsumen.Alfabeta. Bandung.

Jones, P., dan Ioannou, A., 2008, MeasuringGuest Satisfaction in UK Based InternationalHotel Chains: Principles and Practice, Journalof HospitalityManagemement, No. 1, Vol. 4:1-12.

Kotler, Philip. 1996. Marketing Manajemen an Asian Perspective. Prentice Hall. Jakarta.

Lovelock, C. dan L. Wright. 2001. Principles of Service Marketing and Management. Prentice Hall. New Jersey.

M. Zein. 1995. The Important of Experience in Moulding Customer Loyalty Behavior. Kelola No.8/4/1995. Malaysia.

Menteri Agama Republik Indonesia. 2008. Al-Qur'an dan Terjemahannya. PT. Serajaya Santra. Jakarta.

Marzuki.(1983). Metodologi Riset. Yogyakarta: Andi Offset.

Patterson. Evelyn R. dan R. Smith. 2003. Materiality Uncertainty and Earnings Misstatement. The Accounting Review Journal.Vol. 78.

Pamenan, S. 2010. Churn Rate Masih Sangat Tinggi Operator terus genjot kapasitas jaringan mobile data. www.bataviase.co.id diunduh tanggal 17 Maret 2011

Purnamawati, Rr. Siti N. E. 2012.Analisa Faktor-Faktor Yang Mempengaruhi Perpindahan Merek Pada Pelanggan Kartu Prabayar GSM. Instittut Pertanian Bogor. Bogor.

Peppard, Joe dan Phillip R. 1995.The Essence of Business Process Re-Engineering. Pearson PTR.

Porter, M. E. 1980. Competitive Strategy: Techniques for Analyzing Industries and Competitors. Free Press. New York.

Singh, Jagdip. 1988. Consumer Complaint Intentions and Behavior: Definitional and Taxonomical Issues. Journal of Marketing.Vol. 52.No. 1.

Sugiyono. 2005. Metode Penelitian Bisnis. Alfabeta. Bandung.

Sulistyo, Budhi. A. dan Ida. M. 2016. Analisa Pengaruh Perpindahan Merek Melalui Harga, Iklan Dan Ketidakpuasan Konsumen. Management Analysis Journal.Vol. 5.No. 2.Universitas Negeri Semarang. Semarang.

Sekaran, U. 2006. Metode Penelitian Untuk Bisnis 1. Salemba Empat. Jakarta.

Swan, J.E. dan Oliver R.L. 1989. Consumer Perceptions of Interpersonal Equity and Satisfaction in Transactions: A Field Survey Approach. Journal of Marketing.Vol. 53.No. 21.

Tjiptono, Fandy. 1997. Prinsip-prinsip Total Quality Service. Andi Yogyakarta. Yogyakarta. 
Tse dan Wilton. 1988. Kepuasan Pelanggan, jilid 2. Edisi ketiga.PT. Indeks Kelompok Gramedia.Klaten.

Widiyanto, Joko. 2010. SPSS for Windows Untuk Analisis Data Statistik dan Penelitian. BP-FKIP UMS. Surakarta.

Wilkie, William. L. 1990. Cosumer Behavior. John Wiley \& Sons. Canada.

Zein, Satria E. M. 1995. Usul Fikih. PPS IAIN. Jakarta. 